症例

$$
\text { 上腰ヘルニアの } 1 \text { 例 }
$$

福岡大学第 2 外科, 三萩野病院外科*

$\begin{array}{llllll}\text { 田 中 幸 } & \text { 山 } & \text { 裕 } & \text { 高 地 俊 郎* } \\ \text { 平 野 } & \text { 忠* } \text { 白 } \text { 日 高 歩 } & & \end{array}$

自験例は，60歳，女性。1996年 8 月30日左腰背部膨隆を主訴として当院を受診した。 左腰背部に大きさ $8 \times 7 \mathrm{~cm}$ の柔らかく圧痛のない腫瘤を認めた. 腹部超音波, CT およ びMRI 検植により上腰へルニアと診断した。手術所見では, 直径 $2.5 \mathrm{~cm}$ の腹横筋腱膜の 断裂がヘルニア門となっており腎周囲の後腹膜脂肪の脱出を認めた. 術式は周囲組織が 脆弱であったため, ヘルニア門を閉鎖した後 Marlex Mesh ${ }^{\circledR}$ 縫着して補強した. 1999 年現在まで再発をみとめていない.

上腰ヘルニアを臨床において経験することは稀であり，本邦では自験例を含めて37例 の報告がある，その診断は理学的所見から容易であったが, 超音波, CT, MRI 検查がへ ルニアの内容, 周囲との関係を知るうえで有用であった，発見された時点で症例に応じ た外科的修復を行うことを原則としてよい。

索引用語 : ヘルニア, 上腰ヘルニア, 腰三角

\section{緒 言}

腰部には，上腰三角部 (Grynfelt-Lesshaft space) と下腰三角部 (Petit's triangle) と呼ばれる解剖学的 脆弱部がある。しかし，これらの部位にへルニアが発 生することは稀であり, 日常診療において遭遇するこ とはほとんどない.今回われわれは左上腰三角に発生し た稀な上腰へルニアの 1 例を経験したので報告する。

$$
\text { 症例 }
$$

症例：60歳，女性.

主訴: 左腰背部膨隆。

既往歴：57歳の時, 多発性小腸穿孔で小腸切除術.

家族歴：特記事項なし。

現病歴：1992年ごろ, 左腰背部の膨隆に気付いたが 放置していた，徐々に膨隆が増強したため, 精査目的 で1996年 8 月30日入院となった。

入院時現症 : 身長 $152 \mathrm{~cm}$, 体重 $47 \mathrm{~kg}$. 左腰背部に, 立位にて膨隆する $8 \times 7 \mathrm{~cm}$ の柔らかい腫瘤を認めた

(図 1 ).その他には胸腹部に理学的異常所見を認めな かった.

入院時検查所見 : 末梢血, 血液生化学検查邨よび尿 検査に異常を認めなかった。

1999年 9 月16日受付 2000 年 6 月 14 日採用
腹部 CT 検查：左腰背部筋に欠損があり，この部よ り皮下に突出する $4 \times 2.5 \mathrm{~cm}$ の低吸収域の腫瘤像を 認めた（図 2).

腹部超音波検査：右側臥位にて腰背部筋わよび筋膜 の断裂と左腎周囲から皮下に連続する低エコ一領域を 認め, 後腹膜脂肪織の脱出が疑われた. (図 3 ).

MRI 検査：T 1 強調像において, 腰背部筋および筋 膜久損部より腎周囲脂肪に連続する high intensity の 腫瘤像を認めた（図4）。

以上より, 腎周囲脂肪織を内容とする左上腰へルニ アと診断し，1996年 9 月14日手術を行った。

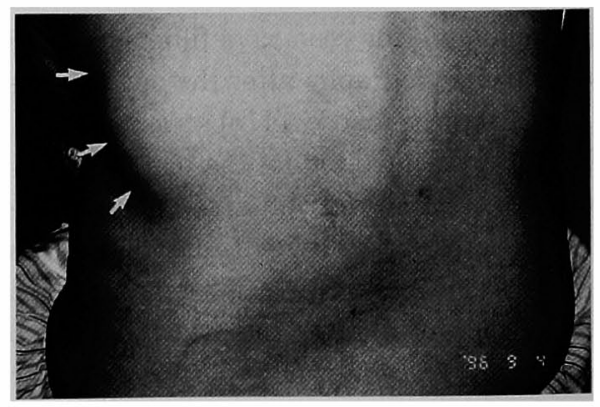

図 1 術前写真：左腰背部に立位にて膨隆する $8 \times 7 \mathrm{~cm}$ の弾性軟の腫瘤を認めた. 


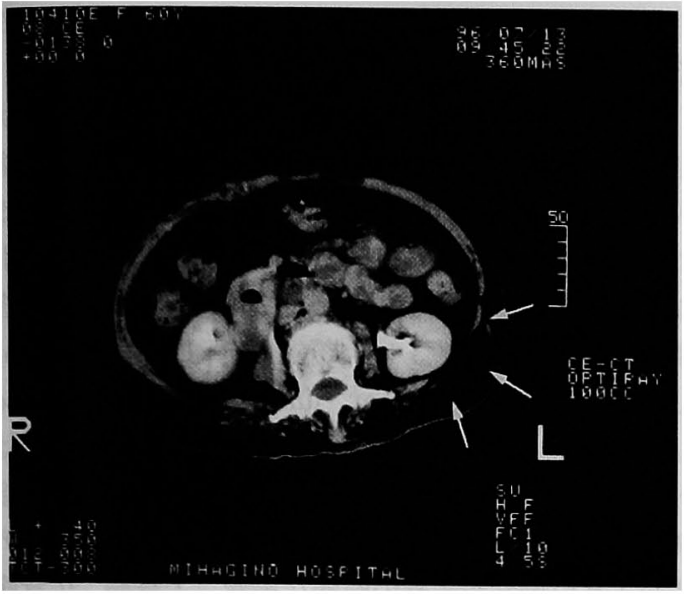

图 2 腹部 CT 検査：左腰背部筋欠損部より皮下に突 出する $4 \times 2.5 \mathrm{~cm}$ の低吸収域の腫瘤を認めた。

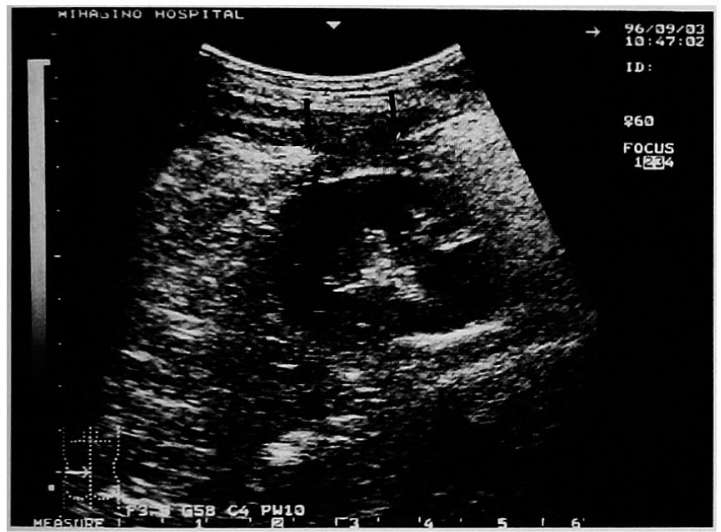

図 3 腹部超音波検査：腰背部筋の断裂と左腎周囲から皮 下に連続する低エコー領域を認め, 後腹膜脂肪織の脱出 が疑われた。

硬膜外麻酔下に右側臥位とし，膨隆の直上をとおる ように第12肋骨部より腸骨稜部まで皮虔に䋛切開を加 えた. 広背筋の前縁を後方に率引すると, 内腹斜筋, 第12肋骨下緑，仙碀筋より構成される上腰三角の中に 矢印のように $2 \times 2.5 \mathrm{~cm}$ のヘルニア門（腹横筋腱膜の 欠損）を確認できた（図 5 ).ヘルニア亯は存在せず， ヘルニア内容は後腹膜脂肪織であった．脱出している 脂肪織を一部切除し，ヘルニア門を直接閉鎖した．周 囲組織が脆弱であったため Marlex Mesh田用いてへ ルニア門部を補修した。

術後経過は良好て翌日には歩行を開始し，第14病日 に退院となった。 3 年後の現在まで再発を認めていな

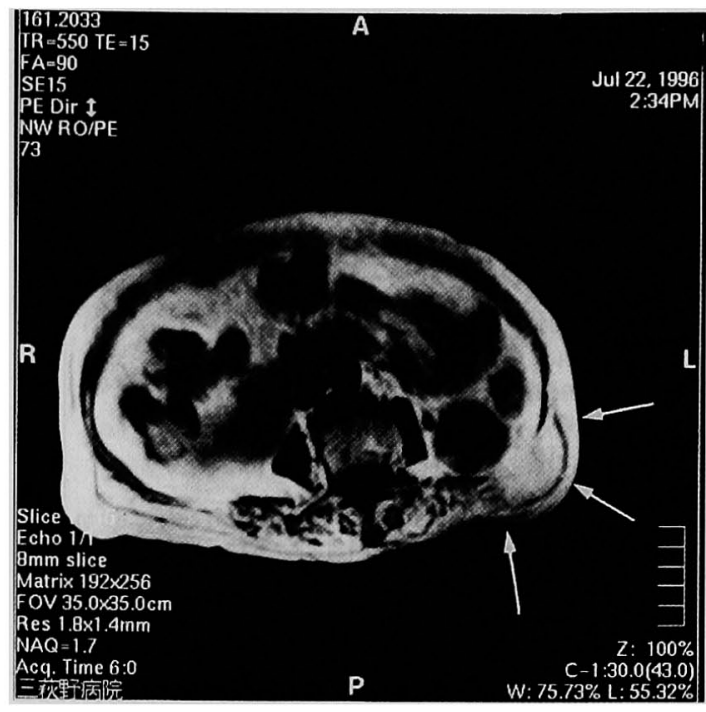

図 4 MRI 検查：T 1 強調像において, 腰背部筋欠損部 より腎周囲筋膜に連続する high intensity の突出した 腫瘤を認めた。

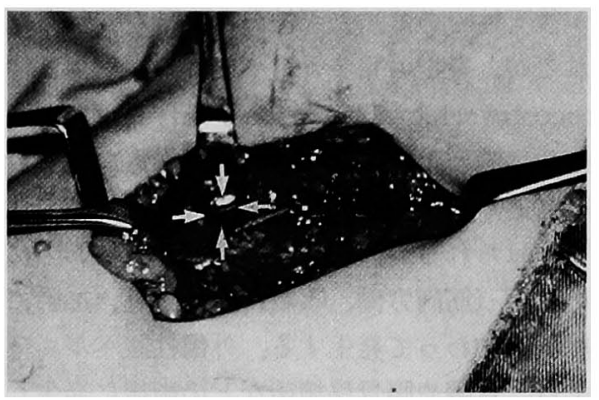

図 5 術中所見：内腹斜筋, 第12肋骨下縁, 仙梀 筋によって構成される上腰三角筋の中に $2 \times$ $2.5 \mathrm{~cm}$ のヘルニア門（矢印）があり，腹横筋お よび腱膜の欠損が確認できた。

w.

\section{考察}

上腰三角は第12肋骨ならびに下後鋸筋下緑を底辺と して, 前方は内腹斜筋後縁で, 後方は仙棘筋前縁で形 成される.この三角部は広背筋と腹横筋腱膜で被覆さ れているにすぎず,特に12肋骨直下で抵抗が最も弱い.

上腰へルニアの本邦報告例は, 著者らが1998年まで の医学中央雑誌より検索した範囲内では自験例を含め て37例1) -17)，40力所である. 年齢は，40歳から90歳(平 均71歳)，男性16例，女性20例，不明 1 例とやや女性に 多くみられた。また，左右差は，左側が24例，右側 8 
6）加藤政隆，浅野元和，加藤全功他：上腰ヘルニア の 1 治験例. Med Postgrad 33:61-64, 1995

7) 岸本弘之, 佐藤尚喜, 葛田啓吾 他：両側性再発上 腰ヘルニアの 1 治験例. 外科 $58: 1292-1295$, 1996

8）多田豊治, 天野信一：両側上腰へルニアの 1 例. 三重医 $40: 17-21 ， 1996$

9）大下 勝, 村田 徹, 宮本好晴：上腰へルニアの 経験. 外科 $58: 918-920,1996$

10)森 和彦, 小林 薰, 浅井聖子他 : 上腰ヘルニア の1例. 日臨外医会誌 $57: 3104,1996$

11）江田 泉, 安原正雄：腰ヘルニアの1例. 岡山医 会誌 $108: 328,1996$

12）柏井英助, 荒木京二郎, 計田一法: 上腰ヘルニア の 1 治験例. 臨外 $51: 515-518,1996$

13）草間俊行, 深沢智基, 三浦和夫 : 高齢者上腰へル 二アの 1 例. 日臨外医会誌 $58: 3048,1997$

14）三枝 隆, 松崎弘明, 木村正之他：上腰へルニア の 1 治験例. 日臨外医会誌 58 (増刊号)：438, 1997

15）松尾 篤, 日下部光彦, 佐藤 功: 上腰ヘルニア の一例。岐阜大医紀 $46: 177,1998$

16）中村好宏, 石部良平, 池江隆正他：術後に鼠径人 ルニアの出現をみた上腰ヘルニアの1例. 臨外 $53: 261-263,1998$

17）河岡 徹, 村岡由紀子, 上野富雄他：Ehlers-Dan$\operatorname{los}$ 症候群に上腰ヘルニアを合併した一例. 日消 外会誌 $31: 676,1998$

18) Fakhry SM, Azizkhan RG: Observations and current operative management of congenital lumbar hernias during infancy. Surg Gynecol Obstet 172:475-479, 1991

19) Hancock BJ, Wiseman NE : Incarcerated congenital lumber hernia associated with the lumbocostovertebral syndorome. J Pediatr Surg $23: 782-783,1988$

20) Lowell DG, Guzzetta PC: Lumbar hernia in a case of posterior meningomyelocele. J Pediatr Surg $21: 913-914,1986$

21) Horovitz IL, Schwarz HA, A Dehan: A Lumbar hernia presenting as an obstructing lesion of the colon. Dis Col Rectum 29 : 742-744, 1986

22) McCarthy MC, Lemmon GW: Traumatic lumbar hernia : A seat belt injury. J Trauma 40 : $121-122,1996$

23) Esposito TJ, Fedorak I : Traumatic lumbar hernia : case report and literature review. J Trauma $37: 123-126,1994$

24) Geis WP, Saletta JD : Lumbar Hernia. by Nyhus LM, Condon RE. Hernia, 3rd Ed. J. B. Lippincott Company, Philadelphia, 1989, p401415

25）安井広明, 寺島 晃, 長谷茂彦他: 後天性腰ヘル ニアの治験一手術法一.手術 11:970-976, 1957

26) Lichtenstein IL: Hernia repair without disability (2nd Ed), ISHIYAKU EUROAMERICA INC, St. Louis, Tokyo, 1986, p202-209

27) Heniford BT, Iannitti DA, Gagner M : Laparoscopic Inferior and superior lumbar hernia repair. Arch Surg 132 : 1141-1144, 1997

\title{
A CASE OF SUPERIOR LUMBAR HERNIA
}

\author{
Koichi TANAKA, Yuichi YAMASHITA, Toshiro TAKACHI*, Tadashi HIRANO* \\ and Takayuki SHIRAKUSA \\ Second Department of Surgery, Fukuoka University, School of Medicine \\ *Department of Surgery, Mihagino Hospital
}

A 60-year-old woman was admitted to the hospital, because of a left flank mass on August 30, 1996. Physical examination showed a $8 \times 7 \mathrm{~cm}$, soft, non-tender, and smooth-surfaced mass. Ultrasonography (US), computed tomography (CT) and magnetic resonance imaging (MRI) offered a diagnosis of superior lumbar hernia. At operation, a well defined defect about around $2.5 \mathrm{~cm}$ diameter in the transversalis fascia was found, and fat tissue surrounding the kidney prolapsed from this defect. The defect was closed by several interrupted sutures, covering the superior lumbar triangle with a Marlex Mesh ${ }^{\circledR}$. The patient had an uneventful recovery. There has been no evidence of recurrence as of 3 years after the operation. The superior lumbar hernia is so rare that only 37 cases including ours have been reported in the Japanese literature. The diagnosis of lumbar hernia is very easy, when we have correct understanding of the disease. US, CT and MRI are valuable to prove useful defining the muscle walls and contents of the hernia. Surgical repair is generally recommended at the time of discovery, if the patient has no special risk factors. 